\title{
Parafiscalities: Problems and Prospects of Legal Regulation
}

\author{
Victor V. Ignatenko ${ }^{a}$, Natalya W. Vasilyeva ${ }^{\text {b }}$ \\ and Yulia W. Pyatkovskaya a* \\ ${ }^{a}$ Institute of Economics, Management and Law \\ Irkutsk National Research Technical University \\ 83 Lermontov Str., Irkutsk, 664074, Russia \\ ${ }^{b}$ Institute of State and Law Baikal State University \\ 11 Lenin Str., Irkutsk, 664003, Russia
}

Received 26.06.2019, received in revised form 04.10.2019, accepted 11.11.2019

The article refers to investigating problems of legal regulation of parafiscal payments and ways of their solving. It marks the increasing number of payments as well as strengthening scientists' interest to the issue in recent years. However, it has not led to legal regulation improvement of the sphere. While studying the issues the authors use the conceptual approach to consider the obligatory payments accumulated out of the budgetary system as "parafiscalities" that is supported by law enforcement practice. Analysing the main characteristics of parafiscal payments, the authors compare them with taxes and levies, separating the last, first of all, according to the purpose of establishing and collecting ones that are expected to satisfy not the state (municipal), but other public social or economic interests. The article also reveals negative sides of current parafiscal system that are mostly caused by legal regulation insufficiency in the sphere. In addition, it highlights the necessity of legislative definition for basic fundamentals to establish, introduce and levy payments providing public and private interests balance and that will ensure protection of payers' rights who make parafiscal payments. The article also raises the problem of strengthening the financial control over the parafiscal payment system that is also possible only in case of complex legal regulation of all obligatory payments coming to the decentralized public funds.

Keywords: parafiscalities, parafiscal payment, obligatory payments, public funds, budget, public interests, taxes and levies.

Research area: financial law, tax law, budget law.

Citation: Ignatenko, V.V., Vasilyeva, N.W., Pyatkovskaya, Yu.W. (2019). Parafiscalities: problems and prospects of legal regulation. J. Sib. Fed. Univ. Humanit. Soc. Sci., 12(11), 2014 2022. DOI: 10.17516/1997-1370-0508.

(C) Siberian Federal University. All rights reserved

* Corresponding author E-mail address: ignatenko_v59@mail.ru; nativi@yandex.ru; julart@yandex.ru ORCID: 0000-0001-6215-3799 (Ignatenko); 0000-0001-6522-6383 (Vasilyeva); 0000-0002-4971-7761 (Pyatkovskaya)

This work is licensed under a Creative Commons Attribution-NonCommercial 4.0 International License (CC BY-NC 4.0). 


\section{Introduction}

In the last decade the Russian and foreign scientists have paid more attention to legal regulation of the obligatory payments coming to the decentralized public funds of private ownership. Both specific studies of parafiscal payments (Kornev, 2016; Romashchenko, 2013) and the issues of legal regulation of parafiscal payments considered within the problematics of perspective obligatory payments were carried out (Vasianina, 2008).

Practice shows the increasing of such payments. In Russia insurance premiums in insurance deposit fund, contributions to Major Repairs Fund, fund-raising for payment to authors, performers, soundtracks and audiovisual works manufacturers for free reproduction of soundtracks and audio-visual works for personal reasons, port charges, payments of public communication service provider to universal service reserve, organizations' payments operating especially radiation-hazardous and nucleardangerous productions and objects.

Similar payments exist also in some foreign states. Thus, for example, in France there are collecting charges to Association of professional training development in transport sphere, audio-visual contribution, airport charge, etc. (Gaudemet, Molinier, 1997; Lamarque, Negrin, Ayrault, 2009). In Romania there are contributions to the private pension funds, payment for monitoring from providers of public networks of electronic communication and providers of electronic communication services (Jurubiță, 2019). With that, these payments are officially admitted, have detailed legal regulation and are studied actively by the doctrine (Romashchenko, 2013).

In the Russian Federation there is a lack of detailed legal regulation for the payments despite their extensive use and recognition by the government.

\section{Statement of the problem}

There are unresolved issues of conceptual character despite the conducted studies of legal regulation on parafiscal payments, Thus, the concept and content of parafiscal payment, the system of the payments, their establishing, introducing, levying and monitoring are the parts of the study.

\section{Theoretical framework}

In the Russian legal doctrine there are various concepts of obligatory payments accumulated out of the budgetary system. Thus, the payments coming to the decentralized public funds are investigated as quasitaxes, non-tax payments, and non-tax revenue. 
The critical analysis of the expressed concepts reveals the essential defects. Considering quasitaxes, it is possible to speak only about the payments that have individual voluntary nature. Non-tax payments and non-tax revenues include all obligatory payments (revenues) that do not have characteristics of the tax regardless of the fund they are subject to charge.

Therefore the conceptual approach is the most reasonable to consider the group of payments defined as "parafiscalities" because this term reflects the main characteristics of the payments. The parafiscal payments group is the specific one of obligatory nature (both individually paid and individually voluntary) coming to the public funds that are out of the budgetary system.

Currently the approach is widely used in legal science, supported by lawenforcement practice and reflected in the opinions of the Constitutional Court of the Russian Federation.

Thus, the Judgment of the Constitutional Court of the Russian Federation No. 15-P "On the case of verification of the validity of Paragraph 2 of Article 16 of the Law of the Russian Federation "On Certification of Products and Services" dated 22 November, 2001, states that obligatory payments have the nature of parafiscalities.

The term "parafiscal" is also used by the other courts (The FAS Resolution in Ural federal district March 22, 2005 No. F09-884/05-AK, the case No. A60-23206/04; The FAS Resolution of Central district September 25, 2009 No. F10-3985/09 on the case No. A14-17128/2008/574/25). The Audit Chamber of the Russian Federation mentions parafiscal payments in the Acts of Audit Chamber of the Russian Federation March 19, 2014 No. PR03-64/03-D.

\section{Methods}

In order to achieve the goals of the study, the authors used the following methods:

1) formal-legal method inspiring logical thinking of legal norms content that regulate the obligatory payments imposed out of the budgetary funds;

2) comparative-historical method helping to study both legal content of the parafiscal payments and the reasons of their origin and development features;

3) method of comparative law that allows using the achievements of foreign legal science when there is a lack of definitions clearly worked out by the Russian legal doctrine;

4) method of complex analysis that makes possible to study the issues of establishing, imposing and levying payments in relation with other legal phenomena. 


\section{Discussion}

Parafiscal payments are always compulsory and it is, in turn, ensured by coercive measures applied by the state. Therefore, very often in a scientific literature there are always parallels between parafiscal payments and fiscal payments. It is stated that such payments have public-law nature in the basis of levying taxes, public purpose of payment, and imperative nature of formation and use of monetary funds to which parafiscal payments are paid (Romashchenko, 2013).

The emphasis on the payment as independent group of obligatory public revenue accumulated out of the budget system is specified by their particular features which allow differentiating them from the present fiscal system.

P.M Godme, defining such payments to budget as charges established for economic and social interests in favour of different subjects except public authority, local governments and their administrative bodies, distinguishes three basic factors, which make them different from other similar payments going into budget:

- interest (economic or social) for which such payments are established whereas in contrast the taxes are levied for financing any expenditure of joint interest;

- collecting such payment in favour of any subject except the public authority, local government or their administrative body (legal entity of public or private law);

- the basis for establishing the charges may not be only law (Godme, 1978).

Most experts when studying the issues related to introducing and establishing parafiscalities emphasize their connection with the necessity of the performance of public functions.

L.V. Romashchenko considers that parafiscalities are aimed at financing public functions in favour of persons performing such functions and at levying on the decisions of public authorities (Romashchenko, 2013).

A. D. Kornev, recognizing the obligatory nature of parafiscal payments, emphasizes their focus on financing public functions performed by the subjects being non-public or local authorities. He also points out their processing to a separate fund (Kornev, 2016).

Thus, the following specific features of parafiscal payments can be identified:

- non-tax revenue to the decentralized funds outside the state budget system;

- targeted payment consisting in financing public needs according to the purpose of the decentralized fund.

Thus, in spite of the similarities of parafiscal payments, taxes and levies (obligatory nature, use of coercive measures established unilaterally etc.), parafiscal payments are different from fiscal payments that go to the budget. Primarily, the fact is that other 
public interests are financed by parafiscal payments rather than by the public (local) ones.

As it is known, taxes and levies established in the Russian Federation are charged for financing activities of public (local) authorities and it is underlined in legal definitions of taxes and levies. According to the provisions of the Article 8 in the Tax Code of Russian Federation, tax is understood as obligatory and individually nonrefundable payment, which is collected from organizations and physical persons by means of the alienation of monetary resources, which belong to them on the basis of the right of ownership, economic jurisdiction or operational management for the purpose of financing the activities of the state and (or) municipalities. A levy is defined as a compulsory contribution collected from organizations and physical persons, the payment of which by public authorities, local government bodies, other authorities and officials providing legally significant acts including the provision of particular rights or issue of permits (licenses) is one condition of the performance in relation to the levy payers, or the payment of which is determined by business operations of certain types within the territory.

The purposes of levying parafiscal payments are considerably different from the above-mentioned purposes that are set for the fiscal system. Thus, according to the provisions of Federal Law No. 177-FZ of 23 December, 2003 “On insuring individuals' deposits made in banks of the Russian Federation", insurance deposits to the Insurance Deposit Fund shall be used only for paying compensation for deposits if a revocation of the license of credit organization occurs. The contributions to the Major Repairs Fund in accordance with the Housing Code should be spent only for the purposes of major repairs of the community property in an apartment building.

The specified differences are important and prove the independence of parafiscalities as a form of obligatory public payment.

However, distinguishing such a type of payment, not all the specialists express positive attitude to parafiscalities. First of all, it is attributed to the fact that traditionally all obligatory payments in Financial Law are considered as an attribute of a state and it is generally accepted that there are obligatory payments only on the accumulation of budget funds.

Moreover, the scientists pay attention to the related problems of parafiscal payments. Thus, nowadays practically in all civilized states, a structured system of obligatory centralized payments has emerged and it provides the balance of fiscal state interests and private interests of revenue payers. This specified system of the Russian Federation 
is based on the principles established by budget legislation (e. g. principle of common (aggregated) expenditure, full budget) as well as fundamental principles of the taxes and levies (e. g. legal establishing of taxes and levies, violation of equal tax burden). However, none of specified rules-principles is applied to the relations resulting from establishing, imposing and levying of parafiscal payments). In addition, the significant weakness of establishing the system of parafiscal management remains the failure of financial control (in comparison of managing budget revenue) (Romashschenko, 2013; Spieb, Thomasius, 2004).

Undoubtedly, budget system is the core of financial system of any state. Therewith, it is necessary to point out that nowadays there is an increasing complexity of financial system, its decentralization takes place, different monetary public funds, which are new for Financial Law, appear and they are used for satisfying public needs. In the circumstances of insufficient centralized revenue it should be noted its inability of financial coverage for all public needs. Thence, some social and economic functions of the state (e. g. education, culture, medical care and social security) are delegated to private subjects. For specified above purposes out of the budget system different monetary funds are created (e. g. protection of deposits, pension coverage, creation of hi-technological products) that predetermine the necessity for their formation also by the method of obligatory payments.

The detailed legal regulation of parafiscalities, which is not enshrined in the Russian Federation nowadays, should even out the above-mentioned problems.

At the legislative level the rules for establishing, imposing and levying two parafiscal payments are only established, namely, insurance payments to the Deposit Insurance Fund, and the payments to the Major Repairs Fund. Meanwhile, only the basis for one of them (Deposit Insurance Fund) is elaborated in detail. The Federal Law "On private deposit insurance in banks of the Russian Federation" defines the obligatory elements, namely, account period (calendar quarter), calculation base (chronological average of calculated period for daily on-balance accounts of deposits), premium rates (base rate, added rate, elevated added rate of insurance), and the procedure for payment of contributions.

Other parafiscal payments are regulated by bylaws (e. g. Russian Government Decree No. 829 of 14 October 2010 "On remuneration for free reproduction of phonograms and audio-visual works for personal purposes"; Russian Government Decree No. 68 of 30 January 2002 "On approval of the Rules for the deduction of means for the formation of reserves intended to ensure the safety of nuclear power plants at all 
stages of their life cycle and development by enterprises and organizations operating especially radiation hazardous and nuclear hazardous industries and facilities (nuclear power plants)".

However, the content of such bylaws on respect of the approaches to the definitions of the elements of such payments (rates, period and the procedure of their payments) are very different.

When resolving such problems it seems appropriate to turn to the experience of foreign states where the issues of legal regulations of parafiscalities has been studied for a long time. In particular, the criteria of their admissibility are worked out, particularly the purpose of levying payments, homogeneous groups of payers are identified, liability of financial objective, group benefit, the requirements for the history of an annex to the budget with the reference to their status and the growth of payments on the type and the extent are defined, as well as the ratio of taxes payments (Romashschenko, 2013).

\section{Conclusion}

For the protection of the parafiscalities payers' rights and balance observance of the fiscal and private interests it is necessary to work out legal regulations of the problems of establishing and levying parafiscal payments.

Nowadays it is obligatory to speak about the system of parafiscal payments because there is no unitary normative framework. First of all, there is essential to establish legal principles and requirements to all parafiscal payments without exception. However, it is important to determine the fundamental principles of establishing and levying parafiscal payments including the criteria of their admissibility inter alia taking into account elimination of preventing violations of the principle of equitable burden and establish control for implementation of legislation in the parafiscal payment sector.

The existing parafiscal levies shall be analysed for the purpose of enforcing the criteria of admissibility when establishing them and also the possibility for replacement by other statutory concepts (in particular, attributing them to budgetary payments). New parafiscal payments shall be established with reasonable restraint and great care.

\section{References}

Godme, P.M. (1978). Finansovoe pravo [Financial Law]. Moscow, Progress, 428 p.

Gaudemet, P.M., Molinier, J. (1997). Public finances. Vol. 2: Taxation [Finances publiques. Tom 2: Fiscalité]. Paris, Montehrestien, 493 p. 
Jurubiță, R. (2019). GEO 114/2018 - Taxes and parafiscal charges due from 2019. Available at: https://home.kpmg/ro/en/home/insights/2019/01/oug-114-impozite-taxeparafiscale-2019.html (accessed 5 June 2019).

Kornev, A.D. (2016). Finansovo-pravovoe regulirovanie parafiskalitetov $v$ Rossiiskoi Federatsii: Avtoreferat dissertatsii na soiskanie uchenoi stepeni kandidata iuridicheskikh nauk [Financial and legal regulation of parafiskalities in the Russian Federation: Synopsis of PhD dissertation]. Moscow, $26 \mathrm{p}$.

Lamarque, J., Négrin, O., Ayrault, L. (2009). General tax law [Droit fiscal general]. Paris, LexisNexis-Litec, 1132 p.

Romashchenko, L.V. (2013). Pravovaia priroda parafiskal'nykh platezhei: avtoref. dis. ... kand. iurid. nauk. [Legal nature of parafiscal payments: Synopsis of PhD dissertation]. Moscow, $26 \mathrm{p}$.

Spieb, C., Thomasius, S. (2004). Parafiscal models for the financing of familypolitical achievements [Parafiskalische Modelle zur Finanzierung familien politischer Leistungen]. Available at: https://www.diw.de/documents/publikationen/73/ diw_01.c.41304.de/diw_rn04-03-36.pdf (accessed 5 June 2019).

Vasianina E.L. (2008). Sistema fiskal'nykh sborov po zakonodatel'stvu Rossiiskoi Federatsii: Avtoreferat dissertatsii na soiskanie uchenoi stepeni kandidata iuridicheskikh nauk [The system of fiscal collecting in accordance with the legislation of the Russian Federation: Synopsis of PhD dissertation]. Ekaterinburg, $26 \mathrm{p}$.

\title{
Парафискалитеты: проблемы и перспективы правового регулирования
}

\begin{abstract}
В. В. Игнатенко ${ }^{\text {a }}$ Н. В. Васильева ${ }^{\tilde{0}}$, О. В. Пятковская ${ }^{\mathrm{a}}$
${ }^{a}$ Институт экономики, управления и права Иркутский наииональный исследовательский технический университет Россия, 664074, Иркутск, ул. Лермонтова, 83 ${ }^{6}$ Институт государства и права Байкальский государственный университет Россия, 664003, Иркутск, ул. Ленина, 11
\end{abstract}

Статья посвящена исследованию проблем правового регулирования парафискальных платежей и определению путей их решения. В статье отмечено как увеличение в последние годы количества таких платежей, так и усиление интереса ученых к данной проблематике, что, однако, до сих пор не привело к улучшению правового 
регулирования обозначенной сферы. При исследовании поставленных проблем за основу взят концептуальный подход к рассмотрению обязательных платежей, аккумулируемых за рамками бюджетной системьл, в качестве «парафискалитетов», что поддерживается правоприменительной практикой. При анализе основных признаков парафискальных платежей авторы статьи проводят их сравнение с налогами и сборами, отграничивая их от последних прежде всего по иели установления и взимания, предполагающей удовлетворение не государственного (мунищипального), а иного публичного социального или экономического интереса. В статье показаны отрицательные сторонь существующей в настоящее время системь парафискалитетов, которые во многом обусловлены недостаточностью правового регулирования данной сферы. Выявлена необходимость законодательного определения основополагающих начал установления, введения и взимания таких платежей, обеспечивающих сбалансированность публичных и частных интересов, что и будет защищать права плательщиков парафискалитетов. В статье также обозначена проблема усиления финансового контроля над системой парафискальных платежей, что возможно лишь в случае комплексного правового регулирования всех обязательных платежей, взимаемых в децентрализованные публичные фонды.

Ключевые слова: парафискалитет, парафискальный платеж, обязательные платежи, публичные фонды, бюджет, публичные интересы, налоги и сборы.

Научная специиальость: 12.00.04 - финансовое право, налоговое право, бюджетное право. 